\title{
【研究ノート】
}

\section{廃アスベストおよびアスベスト含有廃棄物の 溶融処理を目的とした模擬溶融実験}

——溶融条件の検討——

\author{
水上正善* ・ 野田明宏* ・武井宏 幸* \\ 片岡義 雄 ${ }^{*}$. 坂 後充宏 $* *$
}

【要 旨】廃アスベストの処理はこれまで埋立処分を中心に行われてきたが，最終処分場等の寿命は全 国的に残り $2.5 \sim 4.5$ 年と短く, 現在埋め立てに代わる新しい処分方法が求められている。筆者らはこ のたび, 産業廃棄物の処理に伴って発生する主灰と飛灰を使用して $1,500^{\circ} \mathrm{C}$ 以下の低温で廃アスベス卜 およびアスベスト含有廃棄物の溶融処理を検討するラボ実験を行ったので報告する。

今回の実験の結果クリソタイルを $1,300^{\circ} \mathrm{C}, 30$ 分の温度条件 (雾囲気温度) で溶融処理する場合, ク リソタイルと飛灰，主灰の混合比が大きく影響していることがわかった。実験に使用した灰については， 主灰に $\mathrm{Fe}_{2} \mathrm{O}_{3}$ が多く，また飛灰には $\mathrm{CaO}$ が多い。 $\mathrm{SiO}_{2}$ は主に主灰の方に存在するが，その量は廃棄物 の種類之投入量に左右されている。クリソタイルは $\mathrm{Si}$ を多く含んでおり, 全体での $\mathrm{SiO}_{2}, \mathrm{Fe}_{2} \mathrm{O}_{3}$, $\mathrm{CaO}$ の比率が適したときにクリソタイルの溶融が可能になったのではないかと考えられた。この主灰 と飛灰を使用することで，純クリソタイルの比率 $40 \%$ まで溶融することができた。

キーワード：アスベスト, 溶融条件, 飛灰, 主灰, ドラム破砕

\section{1. 序文}

日本においてアスベストは，高度経済成長期における 産業の発展に伴い, 耐火材, 保温材, 自動車部品等で大 量に消費されてきたが，その有害性が指摘され，現在で は一部の商品を除いてアスベストの使用が禁止になって いる。近年中にその一部の商品についてもアスベストの 使用が禁止され，今後アスベストの使用は全面禁止にな ると思われる。現在, 国の各部署にてアスベスト対策が なされ, JIS 規格の改正や大気污染防止法, 石綿障害予 防規則, 建築基準法といった法規制の強化が行われてい る。

原稿受付 2006.6.29原稿受理 2007.1.12

* (株)カムテックス 環境技術センター

***(株)カムテックス 福山本社

連絡先: $=720-0402$ 広島県福山市沼隈町中山南永道 21-1 (踝カムテックス 環境技術センター 水上 正善
今後, アスベスト廃棄物は 2020 年のピークを迎える まで年々増え続け, 平均で年間 150 万 ton のアスベス 卜廃棄物が発生するといわれている。一方, アスベスト の処分についてはこれまで $90 \%$ 以上が埋め立てされて きたが, 安定型最終処分場をはじめとして, 廃棄物の最 終処分場の寿命は全国的に $2.5 \sim 4.5$ 年と短く, 埋め立 てに代わる新しい処分方法の確立が急務とされている ${ }^{1)} 。$ 現在検討が進んでいる埋め立て以外の処分方法の一つ に溶融固化処理があるが， $1,500^{\circ} \mathrm{C}$ 以上の炉内温度が必 要であり ${ }^{2)}$, この高温度が炉壁を傷めるためあまり普及 していないのが現状である。もし溶融固化の際, 添加剤 等を使用して溶融温度を下げることが可能であれば，消 費エネルギーを低下させ普及性が上がると思われる。

一般的に溶融スラグの形成には $\mathrm{SiO}_{2}$ と $\mathrm{Fe}_{2} \mathrm{O}_{3}$, そし て $\mathrm{CaO}$ の存在比が重要で ${ }^{3)}$, 産業廃棄物用の溶融炉を 使用し溶融スラグを形成することを考えた場合, これら の供給源を廃棄物とその焼却灰, つまり主灰と飛灰から 確保する必要がある。飛灰は $\mathrm{CaO}$ を多く含み, $\mathrm{CaO}$ の 供給源として機能するむのと考えられる。また, $\mathrm{SiO}_{2}$ 
は主灰にある程度存在し, 土壤廃棄物等にも多いため, これらを使用することで供給可能と考えられる。しかし 一般的な廃棄物処理施設の場合, $\mathrm{Fe}_{2} \mathrm{O}_{3}$ の供給源は廃棄 物に Fe がない限り確保は困難と考えられる。

筆者らが使用する焼却炉にはドラム罀密閉室内で破 砕し，そのまま焼却炉に投入するドラム破砕搬送設備が あり, 危険物の入ったドラム缶, 斗㩐はこの破砕機を 用いて処理されている。また, 危険物ではない廃棄物が 入った斗罂等は, 破砕機にかけられた後, ピット経由で 焼却炉に投入される。このため当社の主灰は $\mathrm{Fe}_{2} \mathrm{O}_{3}$ の 含有量が高い。したがって $\mathrm{Fe}_{2} \mathrm{O}_{3}$ も主灰から供給可能 である。これまで当社ではこの主灰および飛灰を使用し て炉内温度 $1,500^{\circ} \mathrm{C}$ 以下の低温で溶融スラグを製造し,

リサイクル商品として供給してきた。

今回筆者らはこの金属を豊富に含んだ主灰および飛灰 を添加剤とし，アスベストの炉内温度 $1,300^{\circ} \mathrm{C}$ での低温 溶融固化が可能かどうか, ラボ実験にて検討したので報 告する。

\section{2. アスベストについて}

アスベストにはクリソタイル (白石綿), クロシドラ イト (青石綿)，アモサイト(茶石綿) 等を含む 6 種類が よく知られているが, これらは若干化学組成や性質が異 なっている。融点はクリソタイルが $1,521^{\circ} \mathrm{C}$ と一番高く, 続いてアモサイトの $1,399^{\circ} \mathrm{C}$, そしてクロシドライトの $1,093^{\circ} \mathrm{C}$ と続いている ${ }^{4)}$ 。建築物における吹き付け石綿 には主にクリソタイルが用いられており, 今後, 老朽化 した建物の解体が増えるのに比例して, 建築物からのア スベスト廃棄物が増えるものと思われる。

\section{3. 試薬}

実験には和光純薬工業 (株) 製の市販のアスベストを 使用した。このアスベストを基安化発第 0622001 号「建 材中の石綿含有率の分析方法について」（以後, 基安化 発第 0622001 号）にて分析した結果，100\%のクリソタ イルであることを確認した。マッフル炉は雾囲気温度で $1,700^{\circ} \mathrm{C}$ まで昇温可能なヤマト科学社製の FD 31 を使用 した。この装置は広島県東部工業技術センターの設備で, 今回の実験にご協力をいただき使用させていただいた。 飛灰亡主灰については, 当社の焼却炉から発生したもの を使用した。使用した飛死亡主死についても基安化発第 0622001 号に従って分析し, クリソタイルが不検出 ( $1 \%$ 未満) であることをあらかじめ確認した。また, 飛 灰については, アルカリ度 (中和に必要な $0.02 \mathrm{~N}$ の硫酸
の量（mL）とする）が $380 〜 390$ のむのを使用した。

\section{4. 実験}

\section{1 添加剂の性質}

実験に使用した飛灰および主灰の成分については，蛍 光 $\mathrm{X}$ 線分析法にて金属の組成を調べた。

\section{2 クリソタイルと添加剂の混合条件}

主灰, 飛灰とクリソタイルは, 実際の溶融炉の状況に 合わせ攪找せず，上からかぶせるように加えた。試料の 採取量については, 原則として主灰, 飛灰, クリソタイ ルの合計が $30 \mathrm{~g}$ になるように調整した。一部例外とし てクリソタイルの比率が高い試料については，体積が大 きいため全体が $20 \mathrm{~g}$ になるように試料を調製した。容 器はアルミナルツボを使用し， 3 成分の比率を変えたも のに対して $1,300^{\circ} \mathrm{C}$ で 30 分加熱した。この時の温度は 雾囲気温度を測定している。この温度は $1,350^{\circ} \mathrm{C} て ゙$ 炉 の運転を行った場合の最低温度（变動範囲 1,300 $\left.1,400^{\circ} \mathrm{C}\right)$ であり, より安全サイドでの温度設定となる。 また炉の滞留時間が 30 分であることからこの時間は 30 分とした。実験における温度変化を Fig. 1 に示す。

放冷後中身を確認し繊維状物質の有無を調べた。繊 維状の物質が目視で確認できる場合は溶融不可とした。 繊維状物質が確認された場合, それがクリソタイルの 変性物質（フォレステライト等）なのかどうかは確認し なかった。繊維状物質が目視で確認できないものについ ては粉砕後, 基安化発第 0622001 号に従い分散染色一位 相差顕微鏡および X 線回折法によりクリソタイルの 有無を確認し, クリソタイルがないことを確認できたも のを溶融可とした。X線回折法については定性分析お よび $1 \%$ の定量下限值での定量分析を行った。これらの 結果を基に, 主灰, 飛灰, そしてクリソタイルの 3 成分 で, クリソタイルの溶融可否について三相図を作成し, $1,300^{\circ} \mathrm{C}, 30$ 分での溶融可能濃度領域を確認した。

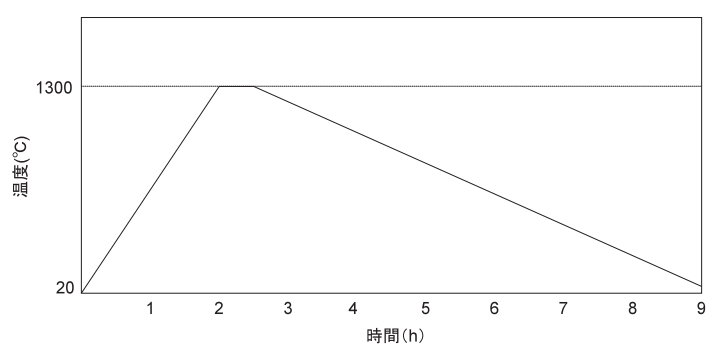

Fig. 1 加熱における昇温設定 (昇温速度 $10^{\circ} \mathrm{C} /$ 分, $1,300^{\circ} \mathrm{C}$ 保持 30 分, その後自然放冷) 


\section{5. 結果}

まず，主灰および飛灰を蛍光 X 線分析法にて分析し た結果，Table 1 に示すように飛灰には $\mathrm{CaO}$ が約 $52 \%$ 含まれていた。 $\mathrm{ZnO}$ と $\mathrm{SiO}_{2}$ はそれぞれ $1.7 \% ， 1.2 \%$ と 少なく，大半が $\mathrm{CaO}$ と $\mathrm{Cl}$ であった。一方，主灰の方は $\mathrm{SiO}_{2}$ が $28 \% ， \mathrm{Fe}_{2} \mathrm{O}_{3}$ が $19 \% ， \mathrm{CaO}$ が $20 \%$ と 3 成分が バランスょく含まれていた。また金属類は， $\mathrm{Fe}_{2} \mathrm{O}_{3}$ 以外 にも $\mathrm{Al}_{2} \mathrm{O}_{3}, \mathrm{TiO}_{2}, \mathrm{CuO}, \mathrm{ZnO}$ 等が若干含まれていた。

この主灰と飛灰を使用し $1,300^{\circ} \mathrm{C}, 30$ 分の温度条件で クリソタイルとの混合条件を検討した結果を三相図にま とめて Fig. 2 に示す。

試料を均一に混合しているわけではないが，三相図を 作成することで混合条件についての参考になるデー夕が 得られると考えた。Fig. 2 より, クリソタイルの存在比 で最大 $40 \%$ まで溶融することかできたが，飛灰と主灰

Table 1 主灰と飛灰の主な成分

\begin{tabular}{|l|c|c|}
\hline & 主 灰 & 飛 灰 \\
\hline $\mathrm{SiO}_{2}$ & $28.0 \%$ & $1.2 \%$ \\
\hline $\mathrm{CaO}$ & $20.0 \%$ & $52.0 \%$ \\
\hline $\mathrm{Fe}_{2} \mathrm{O}_{3}$ & $19.0 \%$ & $0.5 \%$ \\
\hline $\mathrm{Al}_{2} \mathrm{O}_{3}$ & $7.5 \%$ & $<0.1 \%$ \\
\hline $\mathrm{CuO}$ & $1.8 \%$ & $0.4 \%$ \\
\hline $\mathrm{ZnO}$ & $1.7 \%$ & $1.7 \%$ \\
\hline $\mathrm{Cl}$ & $2.9 \%$ & $25.0 \%$ \\
\hline $\mathrm{MgO}$ & $0.0 \%$ & $<0.1 \%$ \\
\hline $\mathrm{TiO}_{2}$ & $5.1 \%$ & $<0.1 \%$ \\
\hline その他 & $14.0 \%$ & $19.2 \%$ \\
\hline
\end{tabular}

（蛍光 X 線分析法による）

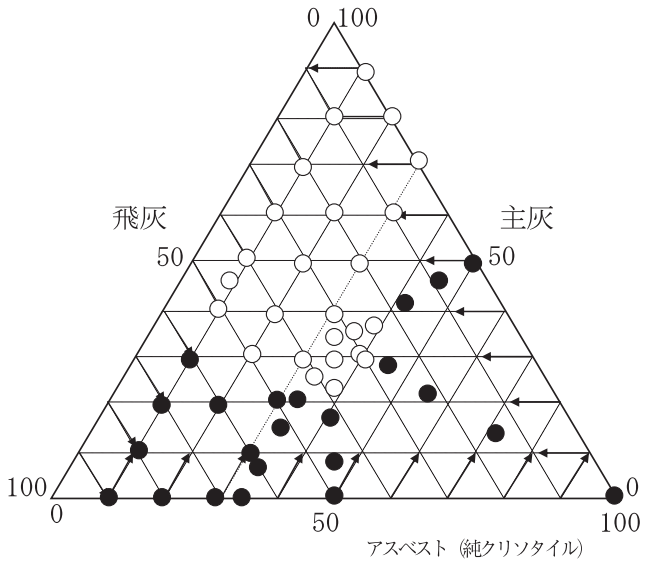

溶融条件： $1,300^{\circ} \mathrm{C}, 30$ 分

$\bigcirc$ : 加熱後, 繊維状物質なし

：加熱後, 瀻維状物質あり

Fig. 2 クリソタイル溶融処理における三相図
のバランスによっては溶融できない条件ああった。この 温度条件でクリソタイルを溶融するためには主灰が少な くと屯 $25 \%$ 程度必要であることがわかった。また，飛 灰の方は $50 \%$ 以下で溶融が可能で，これを超えると溶 融できていないことがわかった。また今回の実験におい て各成分は混合しているわけではなく下から主灰，飛灰， アスベストの順でかぶせるように加えた非混合の状態で あることから，完全に混合しない状態でも，溶融可能で あることがわかった。

\section{6. 考察}

主灰には $\mathrm{SiO}_{2}, \mathrm{CaO}, \mathrm{Fe}_{2} \mathrm{O}_{3}$ がバランスよく含まれ ているものの，主灰のみでは $50 \%$ のクリソタイルを溶 融することができなかった。これはクリソタイルに由来 する $\mathrm{SiO}_{2}$ によって，全体の $\mathrm{SiO}_{2}$ の比率が上がり，金属 と $\mathrm{CaO}$ の量が不足したためと考えられる。ただし， 30\%のクリソタイルまでは溶融することができた。ま た，同じ温度条件において飛灰とクリソタイルの等量混 合物の溶融を試みた場合も溶融することができなかった。 これは $\mathrm{CaO}$ 過多で，金属類が足りなかったためと推測 される。この結果から, 産業廃棄物用の灰溶融炉で主灰, 飛灰とクリソタイルを混合処理する場合は $\mathrm{SiO}_{2}, \mathrm{CaO}$, $\mathrm{Fe}_{2} \mathrm{O}_{3}$ の混合比の検討が必要と思われる。そこで，より 詳しく解析するために成分レベルで Fig. 2 の現象を調 べた。この時, クリソタイルの成分データは文献より引 用した。

Table 1 と Table 2 を基に主灰, 飛灰, クリソタイ ルの 3 者混合時における各成分の濃度を算出し, その中 から $\mathrm{SiO}_{2}, \mathrm{CaO}, \mathrm{Fe}_{2} \mathrm{O}_{3}$ の 3 種類の濃度が合計 $100 \%$ に なるように計算し直して三相図を作成した。Fig. 3 に示 す。

Fig. 3 を見ると, $1,300^{\circ} \mathrm{C}$ での溶融可能範囲は $\mathrm{Fe}_{2} \mathrm{O}_{3}$ が 10\% 以上で， $\mathrm{CaO}$ が 20 ～60\% の間に分布している ことがわかった。文献 ${ }^{3)} の$ 同様の三相図と比べると，文

Table 2 クリソタイルの成分データ（引用）

\begin{tabular}{|l|c|}
\hline 成 分 & クリソタイル* \\
\hline $\mathrm{SiO}_{2}$ & $40.75 \%$ \\
\hline $\mathrm{CaO}$ & $0.35 \%$ \\
\hline $\mathrm{Fe}_{2} \mathrm{O}_{3}$ & $0.44 \%$ \\
\hline $\mathrm{Al}_{2} \mathrm{O}_{3}$ & $3.37 \%$ \\
\hline $\mathrm{FeO}$ & $0.28 \%$ \\
\hline $\mathrm{MnO}$ & $0.03 \%$ \\
\hline $\mathrm{MgO}$ & $41.28 \%$ \\
\hline その他 & $14.19 \%$ \\
\hline
\end{tabular}

※: Cape Asbestos Fibres Ltd. Chrysotile from Cassiar Mine, British Columbia, Canada 


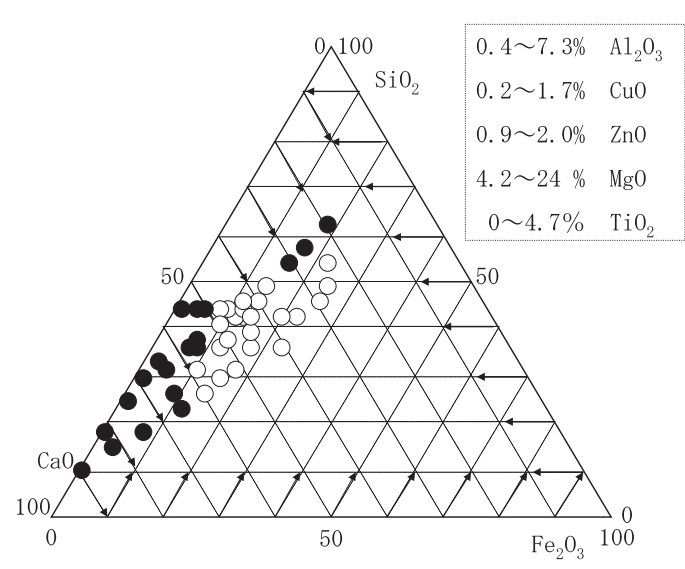

※右上の枠内の数字は，共存成分の濃度変動範囲を示す。 溶融条件： $1,300^{\circ} \mathrm{C}, 30$ 分 $\bigcirc$ について Fig. 2 と同様

Fig. $3 \mathrm{CaO}, \mathrm{SiO}_{2}, \mathrm{Fe}_{2} \mathrm{O}_{3}$ の濃度からみた三相図

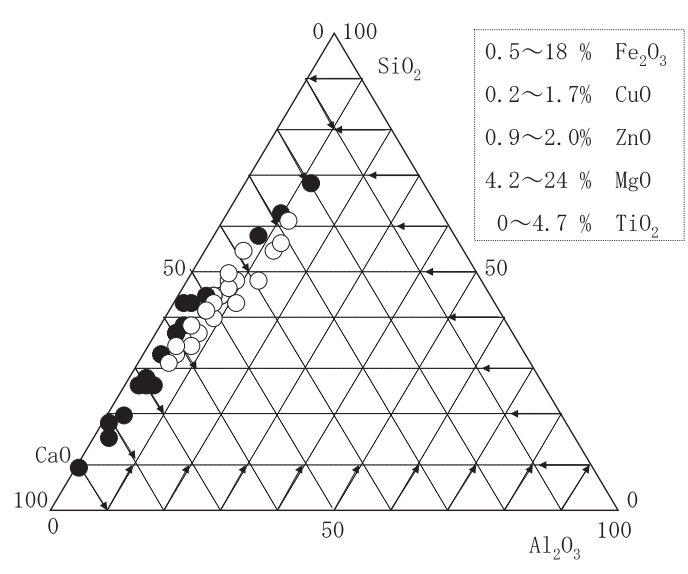

※右上の枠内の数字は, 共存成分の濃度変動範囲を示す。 溶融条件： $1,300^{\circ} \mathrm{C}, 30$ 分 $\bigcirc$ につてはFig. 2 と同様

Fig. $4 \mathrm{CaO}, \mathrm{SiO}_{2}, \mathrm{Al}_{2} \mathrm{O}_{3}$ の濃度から見た三相図

献では中央付近から右下に向けて $1,300^{\circ} \mathrm{C}$ での溶融可能 範囲が広く分布しているのに対し, Fig. 3 では左側に 偏っている結果となった。

Fig. 3 の結果より, Ca の多いスレート廃材や非飛散 化処理を施した吹き付け材中に含まれるクリソタイルを 処理する際は, 投入量に注意する必要があると考えられ た。これについては, 今後詳しく検討することとする。

Fig. 3 と同様に $\mathrm{SiO}_{2}, \mathrm{CaO}, \mathrm{Al}_{2} \mathrm{O}_{3}$ の三相図む作成 した。これを Fig. 4 に示す。この場合は $1,300^{\circ} \mathrm{C}$ での溶 融可能範囲が $\mathrm{Al}_{2} \mathrm{O}_{3}$ の少ないところに偏った結果となり, $\mathrm{Al}_{2} \mathrm{O}_{3} 20 \%$ 以下のところに溶融不可範囲と溶融可能範 囲がそれぞれ見られた。そしてその境界線は $\mathrm{Al}_{2} \mathrm{O}_{3} 5 \%$ 付近のところにあった。
Table 3 模擬の主灰と飛灰で行った溶融実験の結果

\begin{tabular}{|l|l|}
\hline \multicolumn{1}{|c|}{ 模擬灰の種類 } & $1,300^{\circ} \mathrm{C}, 30$ 分で加熱後の状態 \\
\hline $\mathrm{Table} 1$ と同じ組成 & 繊維状物質なし \\
\hline $\mathrm{Fe}_{2} \mathrm{O}_{3}$ のみなし & ほとんど溶融せず \\
\hline $\mathrm{ZnO}$ のみなし & 一部溶融, 繊維状物質あり \\
\hline $\mathrm{CuO}$ のみなし & ほとんど溶融せず \\
\hline $\mathrm{Al}_{2} \mathrm{O}_{3}$ のみなし & 一部溶融, 繊維状物質あり \\
\hline $\mathrm{TiO}_{2}$ のみなし & 一部溶融, 繊維状物質あり \\
\hline
\end{tabular}

※Table 1 と同じ組成で調製した模擬の主灰および飛灰, そし てその組成から 1 種類の金属だけを抜いて調製した模擬の主 灰および飛灰にて同様の実験を行った。金属を抜いた場合そ の金属の代わりに主灰では $\mathrm{SiO}_{2}$, 飛灰では $\mathrm{CaO}$ を添加した。 条件： $1,300^{\circ} \mathrm{C}, 30$ 分

模擬主灰，模擬飛灰，クリソタイル各 $10 \mathrm{~g}$ 使用（各 33\%）

文献 ${ }^{33}$ の同様の三相図と比べると, 文献では中央やや 左の部分に狭い範囲で $1,300^{\circ} \mathrm{C}$ での溶融可能範囲があっ たのに対して, Fig. 4 では左下に細長く伸びている。Fig. 2 のように主灰々飛灰の濃度で見ていた現象も, Fig. 3 やFig. 4 のように成分で見た場合, $\mathrm{Fe}_{2} \mathrm{O}_{3}$ は $30 \%$ 以下， $\mathrm{Al}_{2} \mathrm{O}_{3}$ は $20 \%$ 以下であった。ただしこれは, 共存物質 があってのことと考えられる。そこで, 共存物質の影響 を確認するために模擬灰で実験を行った結果を示す。

Table 3 はこの実験で使用した主灰, 飛灰の成分をむ とに調製した模擬灰にてクリソタイルの溶融実験を行い, 金属の有無による違いを比較したあので, この表からあ 共存金属に何らかの影響を受けている可能性があると考 えられる。これについても, 今後詳しく検討することと する。

今回の実験はアスベスト廃棄物として純クリソタイル を使用して抢り，実際のアスベス卜廃棄物は $5 \sim 30 \%$ 程度のアスベストを含んでいることが多いことから， 40\% の割合でアスベスト廃棄物を投入したとしても, アスベストそのものはそれよりあ少なくなると思われる。 しかし非飛散化処理を行った吹き付け材やスレート等の 廃棄物は $\mathrm{Ca}$ を豊富に含んでいることが多く, 大量に投 入すると $\mathrm{CaO}$ 過多になる可能性があるので, 処理の際 には飛灰の量またはアスベスト廃衰物の投入量を調整す る必要があると考えられる。また, 今回は主灰, 飛灰之 クリソタイルを完全混合せず, 順次上からかぶせただけ の非混合の状態で加熱していることから，貯槽をむつ燃 焼式表面溶融炉等でその貯槽にアスベスト廃棄物を投入 した場合，貯槽内を混合することもなく同条件にて溶融 処理が可能であることが期待される。実機との混合状態 の違いがあるとは思うが，今後実証試験を行う価值のあ る結果となった。 


\section{7. ま と}

産業廃棄物用の焼却炉から排出される飛灰，主灰を使 用してアスベスト廃棄物（クリソタイル等）を $1,300^{\circ} \mathrm{C}$ にて低温溶融処理するための模擬実験を実施した。結果 としてアスベスト廃棄物または飛灰，主灰の投入量の調 節により溶融そのあのは可能であることが示唆された。 今後はアスベスト含有スレート等を使用した実験も行い, また実証実験に向けた安全対策等の検討を行う予定であ る。そしてその際製造されるスラグの性状等についてあ 評価を行う予定である。

アスベスト廃棄物は 2 重の袋に梱包され，未開封のま ま溶融炉に投入されるのが飛散むなく理想的である。燃 焼式の表面溶融炉では容器を燃焼させることが可能であ ることから，アスベスト廃棄物の溶融処理に適している と思われ，溶融温度を $1,500^{\circ} \mathrm{C}$ から $1,300^{\circ} \mathrm{C}$ まで温度を 下げたことによるエネルギーコストの削減と, 容器の燃 焼による若干の燃料消費の削減が期待される。また，炉
内温度を低くできることで普及性が増し, 今後のアスベ ス卜問題対策が推進されることと思われる。

\section{[謝 辞 $]$}

本実験を行うにあたり，設備を使用させていただ いた上，数々の貴重なご助言を賜りました広島県東 部工業技術センターの大石郁氏に深く感謝します。 また，本実験にご協力頂いた関係者の方々に深く御 礼申し上げます。

\section{参 考文 献}

1) 環境省編：環境白書, 平成 17 年版, pp. 106-113(2005)

2 ）公害研究対策センター：官公庁環境専門資料，第 40 巻 別冊号，アスベスト関係資料集，pp. 106-136（2005）

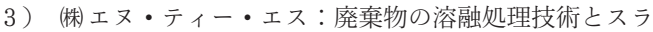
グの有効利用, pp. 3-27（1998）

4）田中信壽編著，松藤敏彦，角田芳忠，東條安匡共著： 廃棄物工学の基礎知識, 技報堂出版, pp. $188-190$ (2006)

\title{
Test Melting Experiment to Investigate Melting Conditions for Asbestos and Wastes that Contain Asbestos
}

\author{
Masayoshi Minakami*, Akihiro Noda*, Hiroyuki Takei* \\ Yoshio Kataoka* and Mitsuhiro Sakajiri** \\ * Kamtecs Co., Ltd., Environment Tech, Center \\ ** Kamtecs Co., Ltd., Fukuyama main office \\ † Correspondence should be addressed to Yoshio Kataoka : \\ Kamtecs Co., Ltd., Environment Tech, Center \\ (21 - 1 Eidou, Nakasanna, Numakuma-cho, Fukuyama-city, Hiroshima, 720 - 0402 Japan)
}

\begin{abstract}
Asbestos waste has been disposed of in landfills for many years. However, since landfills will be unable to accept more waste in 2.5 to 4.5 years, we need new disposal methods for asbestos. This study reports the results of laboratory experiments that examined the disposal of asbestos and waste that contains asbestos by melting with fly ash and ash at temperatures below $1500^{\circ} \mathrm{C}$.

The proportions of chrysotile, ash and fly ash influenced the melting of chrysotile in a test of 30 minutes at a temperature of $1300^{\circ} \mathrm{C}$. The ash used in this experiment included much $\mathrm{Fe}_{2} \mathrm{O}_{3}$, and the fly ash used in this experiment had a lot of $\mathrm{CaO} . \mathrm{SiO}_{2}$ also existed in the ash, but the amount depended on the type and volume of waste. Chrysotile contains much Si. Melting is possible when the proportions of $\mathrm{SiO}_{2}, \mathrm{Fe}_{2} \mathrm{O}_{3}$ and $\mathrm{CaO}$ are suitable. Using ash and fly ash, we were able to melt $40 \%$ pure chrysotile.
\end{abstract}

Key words : asbestos, melting conditions, ash, fly ash, drum crushing 